\title{
Pengaruh Komunikasi dan Iklim Kerja Terhadap Motivasi dan Kinerja Pegawai pada Dinas Tanaman Pangan Holtikultura dan Perkebunan Provinsi Riau
}

\author{
Charina Dwiki Asputri ${ }^{1}$, Suarman $^{2}$, Yulia Efni ${ }^{3}$ \\ ${ }^{1)}$ Pascasarjana Manajemen Universitas Riau, Riau, Indonesia \\ 2) Pascasarjana Fakultas Keguruan dan Ilmu Pendidikan Universitas Riau, Riau, Indonesia \\ ${ }^{3)}$ Pascasarjana Fakultas Ekonomi Universitas Riau, Riau, Indonesia
}

\begin{abstract}
This study aims to examine and analyze the communication spak and the work climate performance in which motivation is regarded as an intervening variable. The study was conducted at the Horticultural Food and Plantation Office of Riait Province.

The data consist of primary data and secondary data. The population of this research are as big as 153 people. The needed data were collected by using a questionnaire addressed to 111 employees of the Hottikultura Food and Agriculture Service Office in Riau Province. The Slovin formula is used to carried the quistionare. Descriptive analysis method is used to describe the characteristics of respondents and research hypotheses by using relevant statistical tests. The variables of communication and work climate are as independent variables, while performance is as the dependent variable, and the motivation is regarded as intervening or mediating variable. The path analysis is used to analyze the collected data.
\end{abstract}

The results of the study indicate that communication directly influences significantly to motivation. Work climate has a direct significant effect on motivation the communication has a significant direct effect on performance. Whole work climate contributes positively to performance. The motivation correlates significantly on performance. Indirectly, motivation has an intensive mediating role in communication and the communication is over performance. The motivation has a positive median role on the influence of the work climate on performance. Increasing the effectiveness of communication and work climate are recommended to optimize employee performance and motivation.

Keywords: Communication, Work Climate, Performance and Motivation

Email Address : charinadwiki@gmail.com

\section{Pendahuluan}

Suatu organisasi dituntut untuk bersaing termasuk meningkatkan aspek motivasi dalam memacu semangat kerja pegawainya. Daya saing suatu organisasi atau perusahaan akan sangat ditentukan oleh kompetensi mutu sumberdaya manusia yang dimilikinya. Apabila sumber daya tersebut diperhatikan secara tepat dengan menghargai bakat dan keahlian mereka, mengembangkan kemampuan mereka, dan mendayagunakannya secara tepat, maka suatu organisasi akan dapat bergerak secara dinamis dan berkembang dengan pesat.

Dinas Tanaman Pangan, Hortikultura dan Perkebunan Provinsi Riau merupakan dinas yang baru terbentuk pada tahun 2017, hasil peleburan Dinas Pertanian dan Peternakan, 
Dinas Perkebunan dan Sekretariat Badan Koordinasi Penyuluhan Provinsi Riau. Berdasarkan Peraturan Daerah Provinsi Riau Nomor 4 Tahun 2016 tentang Pembentukan dan Susunan Perangkat Daerah Provinsi Riau yang ditetapkan pada tanggal 4 November 2016 dan Peraturan Gubernur Riau Nomor 86 Tahun 2016 tentang Kedudukan, Susunan Organisasi,Tugas dan Fungsi serta tata kerja Dinas Tanaman Pangan, Hortikultura dan Perkebunan Provinsi Riau.

Dalam sistem penilaian kinerja Dinas Tanaman Pangan Hortikultura Dan Perkebunan Provinsi Riau memiliki standar penilaian kinerja pegawai yang dinilai dalam rentang nilai 60 kebawah (buruk), nilai 61-69 (kurang), nilai 70-79 (cukup), nilai 80-90 (baik) dan nilai 90 keatas (sangant baik). Adapun target manajemen di setiap tahun adalah agar skor nilai kinerja pegawai berada pada level tertinggi 90 keatas yang mencerminkan tingkat kinerja terbaik yang ditunjukkan pegawai.

Berdasarkan fenomena yang ada menunjukkan masih banyak pegawai yang memiliki kinerja kurang baik dan butuh perhatian pimpinan untuk dapat meningkatkan kinerja pegawai tersebut agar dapat optimal dalam melaksanakan pekerjaan. Hasil penilaian kinerja pegawai menunjukkan rata-rata pegawai masih cukup baik. Maka dari itu, perlu perhatikan terhadap indikator penilaian kinerja agar hasil penilaian kinerja lebih baik lagi sesuai dengan kemampuan dari pegawai secara real dalam pelaksanaan pekerjaan dan tanggung jawab.

Dari fenomena lainnya juga menunjukkan bahwa realisasi waktu kegiatan masih belum bisa mencapai target waktu kegiatan yang diharapkan. Hal ini membuktikan juga bahwa motivasi pegawai pada Dinas Tanaman Pangan Hortikultura Dan Perkebunan Provinsi Riau masih rendah dan perlu di tinjau kembali agar nantinya pegawai mampu mencapai target waktu kegiatan yang telah diharapkan.

Untuk mencapai keberhasilan kerja pegawai salah satunya juga dipengaruhi oleh faktor komunikasi vertikal. Berdasarkan hasil pengamatan yang dilakukan oleh peneliti kepada pegawai di Dinas Tanaman Pangan Hortikultura Dan Perkebunan Provinsi Riau mengenai komunikasi masih terlihat belum berjalan sesuai dengan yang diharapkan, baik antara pimpinan dan pegawai maupun pegawai terhadap pegawai. Kemudian perhatian yang diberikan masih tidak merata, sehingga ini dapat mempengaruhi kinerja.

Pada Dinas Tanaman Pangan Hortikultura Dan Perkebunan Provinsi Riau sering terganggu oleh hal yang ditunjukkan dengan iklim kerja dan suasana kerja yang kurang mendukung terlihat dari beban kerja yang banyak, informasi pekerjaan yang kurang sehingga sering terjadi pertanyaan-pertanyaan dan diskusi yang panjang, kurangnya arahan dari pimpinan.

Berdasarkan latar belakang permasalhan diatas penulis tertarik untuk melakukan penelitian dengan judul " Pengaruh Komunikasi Dan Iklim Kerja Terhadap Motivasi Dan Kinerja Pegawai Pada Dinas Tanaman Pangan Hortikultura Dan Perkebunan Provinsi Riau ". Adapun tujuan penelitian adalah :

1. Untuk mengetahui dan menganali sis pengaruh komunikasi terhadap motivasi pegawai pada Dinas Tanaman Pangan Hortikultura dan Perkebunan Provinsi Riau.

2. Untuk mengetahui dan menganalisis pengaruh iklim kerja terhadap motivasi pegawai pada Dinas Tanaman Pangan Hortikultura dan Perkebunan Provinsi Riau. 
3. Untuk mengetahui dan menganalisis pengaruh komunikasi terhadap kinerja pegawai pada Dinas Tanaman Pangan Hortikultura dan Perkebunan Provinsi Riau.

4. Untuk mengetahui dan menganalisis pengaruh iklim kerja terhadap kinerja pegawai pada Dinas Tanaman Pangan Hortikultura dan Perkebunan Provinsi Riau.

5. Untuk mengetahui dan menganalisis pengaruh motivasi terhadap kinerja pegawai pada Dinas Tanaman Pangan Hortikultura dan Perkebunan Provinsi Riau.

6. Untuk mengetahui dan menganalisis pengaruh komunikasi melalui motivasi terhadap kinerja pegawai pada Dinas Tanaman Pangan Hortikultura dan Perkebunan Provinsi Riau.

7. Untuk mengetahui dan menganalisis pengaruh iklim kerja melalui motivasi terhadap kinerja pegawai pada Dinas Tanaman Pangan Hortikultura dan Perkebunan Provinsi Riau.

Penelitian bertujuan untuk mengetahui dan menganalisis pengaruh langsung komunikasi, iklim kerja dan motivasi terhadap kinerja pegawai pada Dinas Tanaman Pangan Hortikultura dan Perkebunan Provinsi Riau. Kemudian untuk mengetahui dan menganalisis pengaruh komunikasi dan iklim kerja terhadap kinerja melalui motivasi pada Dinas Tanaman Pangan Hortikultura dan Perkebunan Provinsi Riau.

\section{Telaah Pustaka}

\section{Kinerja}

Untuk memperoleh pegawai yang memiliki kinerja baik maka diperlukan penerapan kinerja. Menurut Hasibuan (2012) menyatakan bahwa kinerja adalah suatu hasil kerja yang dicapai seseorang dalam melaksanakan tugas-tugas yang dibebankan kepadanya yang dilaksanakan atas kecakapan, pengalaman dan kesungguhan serta waktu. Dengan kata lain kinerja adalah adalah hasil kerja yang dicapai seseorang dalam melaksanakan tugas yang diberikan kepadanya sesuai dengan kriteria yang ditetapkan. Kemudian menurut Gibson (2009) kinerja dinyatakan baik dan berhasil apabila tujuan yang ditetapkan tercapai. Dan Dessler (2010) juga berpendapat bahwa kinerja karyawan merupakan prestasi kerja, yakni perbandingan antara hasil yang dapat dilihat secara nyata dengan standar kerja yang telah ditetapkan perusahaan.

Wirawan (2015) menyatakan bahwa kinerja karyawan dipengaruhi beberapa faktor, yaitu faktor lingkungan internal organisasi, faktor lingkungan eksternal organisasi, dan faktor internal karyawan. Menurut Timple yang dikutip oleh Mangkunegara (2009) faktor-faktor kinerja terdiri dari faktor internal dan faktor eksternal. Faktor internal adalah faktor yang mempengaruhi kinerja dari sifatsifat karyawan itu sendiri, sedangkan faktor eksternal adalah faktor-faktor yang mempengaruhi kinerja karyawan yang berasal dari lingkungan. Contoh faktor internal meliputi kepuasan kerja, kemampuan, motivasi kerja, dan komitmen organisasi, sedangkan contoh faktor eksternal yaitu budaya organisasi, gaya kepemimpinan, dan iklim organisasi.

Untuk penilaian atas keberhasilan atau kegagalan kinerja karyawan maka perlu dilakukan pengukuran kinerja. Bernardin dan Russel yang dikutip oleh Sudarmanto (2009) menyampaikan bahwa ada 3 indikator untuk mengukur kinerja karyawan. Adapun ketiga indikator tersebut adalah: 
1. Kualitas. Indikator kualitas terkait dengan proses atau hasil mendekati sempurna dalam memenuhi tujuan.

2. Kuantitas. Indikator kuantitas ini terkait dengan satuan jumlah yang dihasilkan.

3. Ketepatan waktu. Indikator ketepatan waktu ini terkait dengan waktu yang diperlukan dalam menyelesaikan pekerjaan atau dalam menghasilkan produk.

Menurut Rivai (2009) menyampaikan bahwa ada 5 indikator untuk mengukur kinerja karyawan. Adapun indikator tersebut adalah:

a. Kualitas. Indikator kualitas terkait dengan proses atau hasil mendekati sempurna dalam memenuhi tujuan.

b. Kuantitas. Indikator kuantitas ini terkait dengan satuan jumlah yang dihasilkan.

c. Tanggung jawab. Kesadaran akan kewajiban karyawan untuk melaksanakan pekerjaan yang diberikan perusahaan

d. Kemampuan bekerja sama. Mampu bekerja sama dengan rekan sekerjanya dalam menyelesaikan pekerjaan yang diberikan.

e. Inisiatif. Kemampuan dalam mengerjakan tugas dan mempunyai inisiatif.

\section{Motivasi}

Motivasi mempersoalkan bagaimana cara mengarahkan daya dan potensi agar bekerja mencapai tujuan yang ditentukan (Hasibuan, 2012). Pada dasarnya seorang bekerja karena keinginan memenuhi kebutuhan hidupnya. Dorongan keinginan pada diri seseorang dengan orang yang lain berbeda sehingga perilaku manusia cenderung beragam di dalam bekerja. Menurut Wibowo (2014) motivasi merupakan dorongan untuk bertindak terhadap serangkaian proses perilaku manusia dengan mempertimbangkan arah, intensitas, dan ketekunan pada pencapaian tujuan.
Kemudian menurut Rivai (2011), motivasi adalah kondisi yang berpengaruh membangkitkan, mengarahkan dan memelihara perilaku yang berhubungan dengan lingkungan kerja.

Motivasi seorang pekerja untuk bekerja biasanya merupakan hal yang rumit, karena motivasi itu melibatkan faktor-faktor individual dan faktor-faktor organisasional. Yang tergolong pada faktor-faktor yang sifatnya individual adalah kebutuhankebutuhan (needs), tujuan-tujuan (goals), sikap (attitudes), dan kemampuan-kemampuan (abilities). Sedangkan yang tergolong pada faktor-faktor yang berasal dari organisasi meliputi pembayaran atau gaji (pay), keamanan pekerjaan (job security), sesama pekerja (coworkers), pengawasan (supervision), pujian (praise), dan pekerjaan itu sendiri (Gomes, 2003).

\section{Komunikasi}

Robbins (2009) menegaskan bahwa komunikasi juga harus dapat dipahami, oleh karenanya komunikasi harus menyertakan keduanya, yaitu penyampaian dan pemahaman arti. Komunikasi merupakan unsur yang penting dalam kehidupan organisasi, baik ditinjau dari segi proses administrasi dan manajemen maupun keterlibatan semua pihak di dalam suatu organisasi (Siagian, 2010).

Komunikasi dari bawahan ke atas sebagai dasar dari kepercayaan seseorang atasan atau pimpinan, komunikasi dari bawahan kepada atasan sering kali menjadi ancaman bagi seorang bawahan, inilah yang mungkin seringkali suara bawahan yang ditunjukan bagi atasan agak sedikit tersendat. Yulianita (2012)

Pada prinsipnya fungsi komunikasi dari bawah ke atas adalah untuk memberikan pengertian mengenai sesuatu. Secara umum 
komunikasi ke bawah dapat diklasifikasikan sebagai berikut.

a. Laporan Hasil Kerja

Laporan hasil kerja dapat di sampaikan oleh seseorang pada bagian tertentu kepada atasannya yang berwenang. Laporan kerja ini biasanya dapat di laksanakan dalam bentuk tulisan maupun lisan. Secara lisan di lakukan dengan tatap muka dalam sebuah rapat, sedangkan secara tulisan dapat ditulis di catatan atau memo.

b. Memberikan Saran

Untuk suksesnya suatu perusahaan, maka saran-saran yang diajukan pihak bawahan juga harus menjadi pertimbangan seorang pimpinan, khususnya bagi pemutusan kebijakan organisasi yang akan dilaksanakan.

c. Memberikan Pendapat

Pendapat karyawan atau bawahan baik yang bersifat positif maupun yang bersifat negative harus dapat disampaikan dari bawahan ke atasan, walaupun pendapat tersebut negative seorang pimpinan menerima dengan baik dan menjadi pemikiran untuk suatu kebijaaksanaan perusahaan pada tahap berikutnya.

d. Usulan Anggaran Biaya

Usulan anggaran yang dibuat bawahan umumnya adalah anggaran yang diminta guna terlaksananya suatu pekerjaan yang memerlukan anggaran.

\section{Iklim Kerja}

Para ahli mengartikan bahwa iklim organisasi sebagai suatu unsur fisik, dimana iklim dapat sebagai suatu atribusi dari organisasi atau sebagai suatu atribusi dari persepsi individu sendiri. Menurut Simamora (2008) bahwa iklim organisasi adalah lingkungan internal atau psikologi organisasi.
Iklim organisasi mempengaruhi praktik dan kebijakan SDM yang diterima oleh anggota organisasi. Perlu diketahui bahwa setiap organisasi akan memiliki iklim organisasi yang berbeda. Menurut Wirawan (2015) bahwa iklim organisasi merupakan kualitas lingkungan internal yang secara relatif terus berlangsung, dialami oleh anggota organisasi, mempengaruhi perilaku setiap anggotanya.

Perubahan yang terjadi baik yang terjadi di dalam (internal) ataupun di luar (eksternal) organisasi akan sangat berpengaruh terhadap iklim kerja organisasi tersebut. Sebagai sebuah entitas yang penting di dalam sebuah organisasi, setiap individu tentunya mengharapkan mampu bekerja di suatu iklim yang kondusif. Iklim yang kondusif akan menciptakan sebuah kondisi yang mendorongnya untuk bekerja dengan giat.

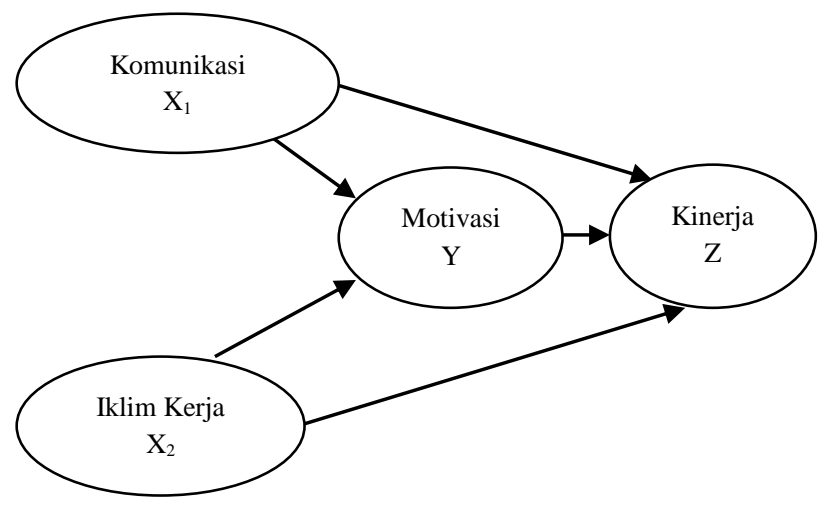

Gambar 2.1 Model Penelitian

Sumber : Pamela (2010), Goris (2007), Mangkunegara (2009), Shonubi (2016), Suarni (2016), Suarningsih (2013), Ayu (2008), Arifin (2015), Kiruja (2013), Handoko (2009), Robbins (2009), Gibson (2009), Davis (2010) Darmawan (2015), Saefullah (2010) dan Yamin (2015)

\section{Hipotesis}


Berdasarkan latar belakang masalah serta konsep teori yang telah dikemukakan diatas dapat ditarik hipotesis sebagai berikut:

1. Komunikasi berpengaruh signifikan terhadap motivasi pegawai pada Dinas Tanaman Pangan Hortikultura dan Perkebunan Provinsi Riau.

2. Iklim kerja berpengaruh signifikan terhadap motivasi pegawai pada Dinas Tanaman Pangan Hortikultura dan Perkebunan Provinsi Riau.

3. Komunikasi berpengaruh signifikan terhadap kinerja pegawai pada Dinas Tanaman Pangan Hortikultura dan Perkebunan Provinsi Riau.

4. Iklim kerja berpengaruh signifikan terhadap kinerja pegawai pada Dinas Tanaman Pangan Hortikultura dan Perkebunan Provinsi Riau.

5. Motivasi berpengaruh signifikan terhadap kinerja pegawai pada Dinas Tanaman Pangan Hortikultura dan Perkebunan Provinsi Riau.

6. Komunikasi berpengaruh signifikan melalui motivasi terhadap kinerja pegawai pada Dinas Tanaman Pangan Hortikultura dan Perkebunan Provinsi Riau.

7. Iklim kerja berpengaruh signifikan melalui motivasi terhadap kinerja pegawai pada Dinas Tanaman Pangan Hortikultura dan Perkebunan Provinsi Riau.

\section{Metode Penelitian}

\section{Lokasi Penelitian}

Penelitian dilakukan pada Dinas Tanaman Pangan Hortikultura Dan Perkebunan Provinsi Riau yang berlokasi di Jalan HR. Soebrantas No. 4 Panam Kota Pekanbaru Provinsi Riau.

\section{Populasi dan Sampel}

Adapun yang menjadi populasi dari penelitian ini adalah seluruh Pegawai pada
Dinas Tanaman Pangan Hortikultura Dan Perkebunan Provinsi Riau yang berjumlah 153 pegawai. Berdasarkan metode slovin, maka diperoleh sampel sebanyak 111 pegawai yang berposisi sebagai pegawai dari level staf sampai level kepala bidang dimana kepala bidang tersebut memiliki interaksi langsung setiap hari dengan bawahan di bidang tersebut pada Dinas Tanaman Pangan Hortikultura Dan Perkebunan Provinsi Riau.

Sesuai dengan kerangka pemikiran maka dapat dibuat dua persamaan struktural yaitu:

$\mathrm{Y}=\rho_{\mathrm{x} 1 \mathrm{y}} \mathrm{X}_{1}+\rho_{\mathrm{x} 2 \mathrm{y}} \mathrm{X}_{2}+\varepsilon_{1}$ $Z=\rho_{\mathrm{x} 1 \mathrm{z}} X_{1}+\rho_{\mathrm{x} 2 \mathrm{z}} X_{2}+\rho_{\mathrm{yz}} \mathrm{Y}+\varepsilon_{2}$

\section{Hasil dan Pembahasan}

Sebelum data dianalisis maka terlebih dahulu dilakukanlah beberapa uji sebagai persyaratan untuk analisis data seperti pengujian instrument data agar valid dan dapat dipercaya dengan menggunakan uji validitas dan uji reabilitas sehingga data tersebut layak untuk dilanjutkan dalam pengolahan data.

Kemudian adapun uji yang dilakukan oleh peneliti selanjutnya adalah uji asumsi klasik seperti uji normalitas, uji multikolinieritas, uji heterokedastisitas dan uji autokorelasi, dimana diperoleh hasilnya sebagai berikut, pada uji normalitas diperoleh hasil penelitian ini telah terdistribusi normal. Kemudian dari uji multikolinieritas diperoleh hasil bahwa tidak terjadi gejala multikolinearitas di antara variabel bebas, dan dari uji heterokedastisitas diperoleh hasil bahwa model regresi dalam penelitian ini tidak terdapat heterokedastisitas karena nilai signifikansi ketiga variabel lebih besar dari 0,05 dan untuk uji autokorelasi diketahui bahwa hasilnya tidak ditemukan autokorelasi dalam model regresi. 
Dengan demikian dari beberapa uji persyaratan analisis yang dilakukan tersebut maka dapat disimpulkan bahwa dapat dilanjutkan analisis data berikutnya seperti terlihat pada hasil dan pembahasan berikut ini.

\section{Komunikasi berpengaruh secara langsung terhadap Motivasi}

Berdasarkan hasil penelitian terdapat pengaruh positif dan signifikan secara langsung komunikasi terhadap motivasi pegawai. Artinya komunikasi merupakan hal yang sangat penting dan harus dilakukan didalam suatu organisasi karena dengan adanya komunikasi yang baik maka tujuan perusahaan akan tercapai.

Berdasarkan pernyataan responden terlihat bahwa nilai tertinggi komunikasi adalah informasi dari pimpinan dapat dipahami oleh bawahan. Hal ini berarti pegawai selalu memahami dan mengerti akan tugas yang diberikan oleh pimpinan kepada pegawai sehingga pegawai bekerja sesuai dengan arahan dari pimpinan dan mencapai hasil yang diharapkan oleh instansi.

Berdasarkan hasil penelitian yang dilakukan oleh Pamela (2010) yang berjudul Middle Management Communication and Interaction Practices and Their Influence On Employee Satisfaction and Motivation. Hasil penelitiannya menunjukkan bahwa terdapat hubungan yang positif antara komunikasi manajerial yang efektif dengan pengaruh terhadap kepuasan kerja karyawan dan motivasi kerja.

\section{Iklim kerja berpengaruh secara langsung terhadap Motivasi}

Berdasarkan hasil penelitian terdapat pengaruh positif dan signifikan secara langsung iklim kerja terhadap motivasi pegawai. Artinya semakin kondusif iklim kerja yang dirasakan oleh pegawai maka akan semakin tinggi motivasi pegawai untuk bekerja.

Berdasarkan pernyataan responden terlihat bahwa nilai tertinggi adalah pernyataan pegawai akan melaksanakan kepercayaan yang diberikan pimpinan kepada pegawai. Artinya pegawai selalu percaya dan mengikuti arahan tugas yang diberikan oleh pimpinan kepadanya.

Berdasarkan hasil penelitian yang dilakukan oleh Budianto (2017) yang berjudul Iklim Kerja berpengaruh terhadap Motivasi dan Kinerja Pegawai: Studi Pada Perbankan di Wilayah Kabupaten Ciamis. Hasil penelitiannya menunjukkan bahwa iklim kerja berpengaruh positif dan signifikan terhadap motivasi kerja pegawai.

\section{Komunikasi berpengaruh secara langsung terhadap Kinerja}

Berdasarkan hasil penelitian terdapat pengaruh positif dan signifikan secara langsung komunikasi terhadap kinerja pegawai. Artinya semakin baik komunikasi yang terjalin antara sesama pegawai dan pimpinan maka akan semakin baik juga kinerja yang dihasilkan pegawai.

Berdasarkan tanggapan responden terlihat bahwa nilai tertinggi adalah informasi dari pimpinan dapat dipahami oleh bawahan. Artinya dalam hal penyampaian informasi pada prosesnya tidak terdapat kendala dimana informasi yang diberikan selalu tepat sasaran sehingga prosedur kerja berjalan dengan baik dan mencapai tujuan perusahaan yang optimal.

Berdasarkan hasil penelitian yang dilakukan oleh Najih (2017) tentang Efektivitas Komunikasi Organisasi Pimpinan Dan Kepuasan Kerja Terhadap Kinerja Karyawan Di Universitas Pesantren Tinggi Darul Ulum Jombang. Hasil penelitiannya menunjukkan bahwa efektivitas komunikasi organisasi 
pimpinan berpengaruh terhadap kinerja karyawan. Hal ini mendukung teori bahwa semakin efektif komunikasi yang dilakukan oleh pimpinan dan kepuasan kerja maka semakin meningkat kinerja karyawan.

\section{Iklim Kerja berpengaruh secara langsung terhadap Kinerja}

Berdasarkan hasil penelitian terdapat pengaruh positif dan signifikan secara langsung iklim kerja terhadap kinerja pegawai. Artinya semakin kondusif iklim kerja yang dirasakan oleh pegawai maka akan semakin tinggi tingkat kinerja dari pegawai tersebut.

Berdasarkan tanggapan responden terlihat bahwa nilai tertinggi adalah pegawai akan melaksanakan kepercayaan yang diberikan pimpinan kepada pegawai. Artinya pegawai selalu percaya dan mengikuti arahan tugas yang diberikan oleh pimpinan kepadanya agar tercapai hasil yang diharapkan oleh instansi.

Berdasarkan hasil penelitian yang dilakukan oleh Suarni (2016) tentang pengaruh Kepemimpinan Dan Iklim Kerja Terhadap Kinerja Pegawai Negeri Sipil (PNS) Pada Badan Perencanaan Penelitian Dan Pembangunan Daerah (Bappeda) Kabupaten Morowali. Hasil penelitiannya membuktikan bahwa kepemimpinan dan iklim kerja berpengaruh signifikan terhadap kinerja pegawai secara simultan maupun secara parsial.

\section{Motivasi berpengaruh secara langsung terhadap Kinerja}

Berdasarkan hasil penelitian terdapat pengaruh positif dan signifikan secara langsung motivasi terhadap kinerja pegawai. Artinya semakin baik motivasi yang ada dalam diri pegawai maka akan semakin baik kinerja pegawai tersebut.
Berdasarkan tanggapan responden terlihat bahwa nilai tertinggi adalah remunerasi/ imbalan kerja seperti tunjangan yang diberikan oleh instansi membuat pegawai bekerja dengan baik. Artinya dalam hal memotivasi pegawai untuk bekerja instansi memberikan imbalan sesuai dengan hasil kerja yang dicapai oleh pegawai. Dengan imbalan yang diberikan kepada pegawai instansi berharap pegawai akan bisa mencapai hasil kerja yang diharapkan.

Berdasarkan hasil penelitian yang dilakukan oleh Darmawan (2015) yang meneliti tentang pengaruh Komunikasi, Komitmen Organisasi Dan Motivasi Terhadap Kinerja Pegawai Inspektorat Kota Palu. Hasil penelitiannya menunjukkan bahwa dengan regresi membuktikan variabel komunikasi, komitmen organisasi dan motivasi memberikan pengaruh yang positif terhadap kinerja karyawan secara simultan maupun secara parsial.

\section{Komunikasi berpengaruh secara tidak} langsung terhadap Kinerja melalui Motivasi

Berdasarkan hasil penelitian diketahui bahwa motivasi mampu memediasi pengaruh dari komunikasi terhadap kinerja. Komunikasi berpengaruh positif dan signifikan terhadap kinerja pegawai melalui motivasi. Dengan adanya variabel motivasi akan mempengaruhi hubungan antara komunikasi dan kinerja yang optimal.

Berdasarkan tanggapan responden terlihat bahwa nilai tertinggi komunikasi adalah informasi dari pimpinan dapat dipahami oleh bawahan. Hal ini berarti pegawai selalu memahami dan mengerti akan tugas yang diberikan kepadanya.

Berdasarkan penelitian yang dilakukan oleh Darmawan (2015) semakin baik komunikasi yang terjadi antara pegawai, 
komitmen yang kuat terhadap organisasi dan motivasi yang tinggi dimiliki oleh pegawai maka akan semakin meningkatkan kinerja pegawai.

\section{Iklim Kerja berpengaruh secara tidak} langsung terhadap Kinerja melalui Motivasi

Berdasarkan hasil penelitian diketahui bahwa motivasi mampu memediasi pengaruh dari iklim kerja terhadap kinerja. Iklim kerja berpengaruh positif dan signifikan terhadap kinerja pegawai melalui motivasi. Dengan adanya variabel motivasi akan mempengaruhi hubungan antara iklim kerja dan kinerja yang optimal.

Berdasarkan tanggapan responden terlihat bahwa nilai tertinggi iklim kerja adalah pegawai akan melaksanakan kepercayaan yang diberikan pimpinan kepada pegawai. Artinya pegawai selalu percaya dan mengikuti arahan tugas yang diberikan oleh pimpinan.

Berdasarkan penelitian yang dilakukan oleh Yamin (2015) iklim kerja sebagai suatu yang dapat diukur pada lingkungan kerja baik secara langsung maupun tidak langsung berpengaruh pada pegawai dan pekerjaannya dimana tempat mereka bekerja dengan asumsi akan berpengaruh pada motivasi dan perilaku karyawan dan akan berdampak pada kinerja pegawai.

\section{Kontribusi Komunikasi dan Iklim kerja Terhadap Kinerja melalui Motivasi}

Berdasarkan hasil pengolahan menggunakan SPSS 21.0 nilai koefisien determinasi $\left(\mathrm{R}^{2}\right)$ sebesar 0,449 . Artinya adalah bahwa pengaruh komunikasi dan iklim kerja terhadap motivasi adalah sebesar 44,9\%, sedangkan sisanya $55,1 \%$ dipengaruhi oleh variabel lain tidak dimasukkan dalam pengujian ini.
Berdasarkan hasil pengolahan menggunakan SPSS 21.0 diperoleh nilai koefisien determinasi $\left(\mathrm{R}^{2}\right)$ sebesar 0,437. Artinya adalah bahwa pengaruh komunikasi, iklim kerja dan motivasi adalah sebesar 43,7\%, sedangkan sisanya $56,3 \%$ dipengaruhi oleh variabel lain yang tidak dimasukkan dalam pengujian ini.

Dari hasil regresi 1 dan regresi 2 di atas maka dapat diketahui ketepatan model path dalam penelitian ini dengan persamaan:

$$
\begin{aligned}
\mathrm{R}^{2} \text { model } & =1-\left(1-\mathrm{R}^{2}\right)\left(1-\mathrm{R}^{2}{ }_{2}\right) \\
& =1-(1-0,449)(1-0,437) \\
& =1-(0,551)(0,563) \\
& =1-0,31021 \\
& =0,68979=0,690
\end{aligned}
$$

Diperoleh nilai ketepatan model sebesar 0,690. Artinya adalah bahwa kontribusi model untuk menjelaskan hubungan struktural dari variabel yang diteliti adalah sebesar 69\% dan sisanya sebesar $31 \%$ dijelaskan oleh variabel lain yang tidak terdapat dalam model penelitian ini.

\section{Kesimpulan}

\section{Kesimpulan}

Berdasarkan hasil analisis penelitian dan pembahasan yang telah diuraikan sebelumnya, maka kesimpulan dalam penelitian ini adalah:

1. Semakin baik komunikasi maka semakin baik pula motivasi pegawainya dalam bekerja. Sebaliknya semakin rendah komunikasi maka semakin rendah motivasi pegawainya untuk bekerja.

2. Semakin baik iklim kerja maka semakin baik pula motivasi pegawainya dalam bekerja. Sebaliknya semakin rendah iklim kerja maka semakin rendah motivasi pegawainya untuk bekerja. 
3. Semakin baik komunikasi organisasi maka semakin baik pula kinerja pegawainya. Sebaliknya semakin rendah komunikasi organisasi maka semakin rendah kinerja pegawai.

4. Semakin baik iklim kerja organisasi maka semakin baik pula kinerja pegawainya. Sebaliknya semakin rendah iklim kerja organisasi maka semakin rendah kinerja pegawai.

5. Semakin baik dan meningkat motivasi kerja yang diberikan terhadap pegawai, maka kinerja pegawai akan semakin meningkat. Sebaliknya semakin rendah motivasi kerja yang diberikan kepada pegawai, maka semakin rendah kinerja pegawai.

6. Semakin baik komunikasi organisasi yang didukung dengan motivasi yang tinggi maka semakin baik pula kinerja pegawainya.

7. Semakin baik iklim kerja organisasi yang didukung dengan motivasi yang tinggi maka semakin baik pula kinerja pegawainya.

\section{Saran}

Berdasarkan hasil penelitian dan kesimpulan diatas, penulis memberikan masukan sebagai berikut:

1. Untuk menunjang kinerja pihak manajemen instansi agar lebih memperhatikan pegawai yang dapat menyelesaikan pekerjaan tepat waktu atau lebih cepat dari batas waktu yang ditetapkan boleh diberikan penghargaan atau kenaikan posisi jabatan serta kenaikan gaji atas hasil usahanya dalam mencapai target pekerjaan.

2. Untuk menunjang motivasi pihak manajemen instansi dalam meningkatkan kinerja pegawai dapat dilakukan dengan cara memberikan motivasi bagi pegawai agar semangat bekerja dan memiliki kreatif dalam bekerja. Perlu pula kepekaan untuk sesegera mungkin membantu pekerjaan rekan kerja setelah pekerjaan sendiri selesai, sehingga disamping melakukan pekerjaan kantor, pegawai juga melakukan interaksi antara sesama pegawai.

3. Untuk menunjang komunikasi pihak manajemen instansi sebaiknya melakukan pengawasan secara langsung agar dapat mengurangi sedikit beban pegawai yang mengalami keterlambatan dalam menyelesaikan pekerjaannya.

4. Untuk menunjang iklim kerja pihak manajemen instansi sebaiknya lebih melibatkan pegawai dalam semua pekerjaan seperti melibatkan dalam hal pemberian tanggung jawab pekerjaan dan wewenang kepada pegawai karena hal ini akan meningkatkan kinerja dan menimbulkan motivasi dalam bekerja.

5. Bagi peneliti yang tertarik dalam bidang yang sama, perlu dipertimbangkan pengaruh faktor lain selain komunikasi dan iklim kerja. Faktor lain tersebut dapat berupa pengaruh faktor eksternal atau pengaruh internal terhadap kinerja pegawai. Di samping itu, penelitian dapat juga dikembangkan dengan tidak hanya meneliti kinerja pegawai saja akan tetapi dapat dikaitkan dengan variable lainnya selain motivasi. Penelitian dengan topik sama atau di perluas di organisasi lainnya perlu juga dilakukan untuk memperoleh gambaran dan perbandingan yang lebih jelas dalam pengembangan komunikasi dan iklim kerja terhadap kinerja yang didukung oleh motivasi di organisasi seluruh indonesia. 


\section{Daftar Pustaka}

Arifin, H. Muhammad. 2015. The Influence of Competence, Motivation, and Organisational Culture to High School Teacher Job Satisfaction and Performance. International Education Studies. Vol. 8. Desember. p.38-45

Ayu, Ida Brahmasari. 2008. Pengaruh Motivasi Kerja, Kepemimpinan dan Budaya Organisasi Terhadap Kepuasan Kerja Karyawan serta Dampaknya pada Kinerja Karyawan (Studi kasus pada PT. Pei Hai International Wiratama Indonesia). Jurnal Manajemen dan Kewirausahaan. Vol. 10. September. p.124-135

Darmawan. 2015. Pengaruh Komunikasi, Komitmen Organisasi Dan Motivasi Terhadap Kinerja Pegawai Inspektorat Kota Palu. e-Jurnal Katalogis. Vol. 3. Mei. p.205-214

Dessler, Gary. 2010. Manajemen Sumber Daya Manusia. PT. Indeks. Jakarta.

Ferdinand, Augusty. 2006. Metode Penelitian Manajemen: Pedoman Penelitian untuk skripsi, Tesis dan Disertai Ilmu Manajemen. Universitas Diponegoro. Semarang.

Gibson et al. 2009. Organisasi edisi kelima. Erlangga. Jakarta.

Gomes, Faustino Cardoso. 2003. Manajemen Sumber Daya Manusia. Andi Offset. Jakarta.

Goris, Jose R. 2007. Effects Of Satisfaction With Communication On The Relationship Between Individual-Job
Congruence And Job Performance/Satisfaction. Journal of Management Development 26. July. p. $737-752$

Handoko, T. Hani. 2009. Manajemen Sumber Daya Manusia Cetakan IX Jilid I BPFE UGM. Yogyakarta.

Hasibuan, Malayu. 2012. Manajemen Sumber Daya Manusia. Bumi Aksara. Jakarta.

Kiruja, Mukuru. 2013. Effect of Motivation on Employee Performance In Public Middle Level Technical Training Institutions In Kenya. Kiruja EK \& Elegwa Mukur. Vol. 2. Agustus. p. 7382

Mangkunegara, Anwar Prabu. 2009. Manajemen Sumber Daya Manusia Perusahaan. PT Remaja Rosdakarya. Bandung.

Pamela, Armstrong Arons. 2010. Middle Management Communication and Interaction Practices and Their Influence On Employee Satisfaction and Motivation. Dissertation. University Of Phoenix.

Rivai, Veithzal. 2011. Manajemen Sumber Daya Manusia Untuk Perusahaan Dari Teori ke Praktik. Raja Grafindo Persada. Jakarta.

Robbins, S.P. 2009. Perilaku Organisasi. Salemba Empat. Jakarta.

Saefullah, Kurniawan. 2010. Pengantar Manajemen. Kencana. Jakarta.

Shonubi, A O. 2016. The Impact Of Effective Communication On Organizational 
FE Universitas Maritim Raja Ali Haji

Performance. Valley International Journals. Vol. 3. Maret. p. 1904-1914

Siagian, Sondang P. 2010. Manajemen Sumber Daya Manusia. Bumi Aksara. Jakarta.

Simamora, Henry. 2008. Manajemen Sumber Daya Manusia Edisi 2. STIE YKPN. Yogyakarta.

Suarni. 2016. Pengaruh Kepemimpinan Dan Iklim Kerja Terhadap Kinerja Pegawai Negeri Sipil (PNS) Pada Badan Perencanaan Penelitian Dan Pembangunan Daerah (Bappeda) Kabupaten Morowali. e Jurnal Katalogis. Vol. 4. Agustus. p. 126132

Suarningsih, Ni Luh Putu. 2013. Pengaruh Iklim Organisasi Terhadap Komitmen Organisasional Dan Kinerja Karyawan Di Rumah Sakit. Jurnal aplikasi manajemen. Vol. 11. Juni. p. 233-240

Sudarmanto. 2009. Kinerja dan Pengembangan Kompetensi SDM (Teori, Dimensi Pengukuran dan Implementasi dalam Organisasi). Pustaka Pelajar. Yogyakarta.

Wirawan. 2015. Manajemen Sumber Daya Manusia Indonesia. PT Raja Grafindo Persada. Jakarta.

Wibowo. 2016. Manajemen Kinerja. PT. Rajawali Pers. Jakarta.

Yulianita, Neni. 2012. Dasar-dasar Public Relation. Pusat Penerbitan Universitas (P2U). Bandung.
Yamin, Muh Nur. 2015. Iklim Dan Motivasi Kerja Pegawai Pada Program Pascasajana Universitas Halu Oleo. November. p. 108-115 